\title{
周期的打叮のタイミング調整における呼吸の役割
}

\author{
○隅田寸み子 岩永誠 \\ (広島大学大学院総合科学研究科) \\ キーワード: 呼吸, 周期依存タイミング, グループ化
}

\begin{abstract}
Relation of respiration cycles and timing control of periodic tapping Sumiko SUMIDA Makoto IWANAGA

(Graduate School of Arts and Sciences, Hiroshima Univ.)

Key words: respiration, periodic timing, grouping
\end{abstract}

\section{序 論}

ジャンケンをするときに手を出すタイミングが合わなけれ ば，やり直す事になる。このように，日常生活で他者と協調 して身体運動をするとき，タイミングが合わないと物事は円 滑に進まない。タイミングは「最も有効な時間条件を作り出 すこと」と定義されている（Conrad, 1955）ものの，具体的に 何を手がかりとしてタイミングを合わせているかについての 検討は，さほどなされていない。他者とタイミングが合うこ とは「息が合う」と比喻的に表現されているように，二者の ギターアンサンブルにおいて安静時よりも演奏時, また初心 者同士や高難易度の曲のほうが，より呼吸が一致すると報告 されている（古浦，1990）。また，4人で同時リズムタッピン グを行い，打拍中の脳波のピーク周波数に倍化・半減する現 象が報告されている（吉田ら，2007）。これは拍をまとめる, あるいは 1 拍を半分に分割して処理していることを示唆して いる。本研究では，周期に依存したタイミング制御をすると き，呼吸がどのように影響しているのかについて，呼吸周期 およびグループ化の視点から，探索的に検討を行う事を目的 とする。仮説は次の 2 点である。(1)タイミングを合わせるた めに呼吸を合わせているだろう。(2)呼吸周期より速いテンポ 時は拍をグループ化して呼吸を合わせているだろう。

\section{方 法}

実験時期と分析対象者：2009年 9 月に実験を実施。実験参加 者は大学生と大学院生 13 名（男性 7 名, 女性 6 名）課題： 連続的な電子ピアノ音に，ピアノ音呈示と同時刻に，電子ド ラムを用いて打吒させる同期タッピング課題 音刺激 : テン ポは 6 種類設定し，20bpm を基準とし，その 1.3 の 乗（20, 26, 34, 43, 57,74） とした。これは, 呈示周期が呼吸周期の整 数倍になりにくいようにするためである。6 条件の呈示順序 はカウンターバランスをとった。各テンポ 2 分間呈示した。

手続き : 実験室入室後, 生理指標測定器を装着し, 生理反応 を 3 分間と主観反応のベースを測定した。次に，参加者が快 適に感じるテンポ（パーソナルテンポ）で 2 分間タッピング をするよう教示し，打吒中に生理反応および音響情報を測定 した。その後 6 種類のテンポを呈示し打吒させた。1 1 テンポ ごとに生理指標を測定し，1 テンポ終了直後に気分調査票に 記入させた。1テンポ終了ごとに 2.5 分の休䟤を取って, 次の 実験条件を実施した。休秘時には写真集を見せ，直前の刺激 のテンポの影響を減少させた。6 テンポ終了後に実験への印 象の内省報告をとった。指標: 生理指標: 呼吸, 心拍, 筋電 音響情報 : 刺激音波形, 電子ドラム音波形 主観指標 : 実験 用に作成した気分調査票（うまく合わせることができた，快 適な速さだった等）

結 果 と
(1) 打叨中の呼吸周期の変化

テンポによる呼吸周期の統計值を Table 1 に示す。全参加者 のテンポ間の平均值の差の有無を 1 要因の分散分析を行った
結果, 有意差は認められなかった $(F(5,69)=0.647$ (n.s.)。個人ご との分析では, 全参加者において 6 テンポの呼吸周期間に有 意差がみとめられた $\left(F_{S}=2.0 \sim 30.5\right)$ これは, 同じテンポでも 個人によりテンポの変化に応じた呼吸周期の変化が, 増える 場合と減る場合が認められたため, 全体の平均においては有 意な差が示されなかったと考えられる。

Table1 打叨中の呼吸周期の記述統計

\begin{tabular}{cccccc}
\hline & 度数 & 最小值 & 最大値 & 平均値 & SD \\
\hline 安静時 & 366 & 1.53 & 5.66 & 4.09 & 1.15 \\
pt & 484 & 1.51 & 6.70 & 3.11 & 0.66 \\
$20 \mathrm{bpm}$ & 491 & 1.60 & 5.10 & 3.10 & 0.55 \\
$26 \mathrm{bpm}$ & 472 & 1.50 & 7.10 & 2.97 & 0.78 \\
$33 \mathrm{bpm}$ & 474 & 2.00 & 8.00 & 3.18 & 0.55 \\
$43 \mathrm{bpm}$ & 451 & 1.10 & 5.60 & 3.08 & 0.64 \\
$57 \mathrm{bpm}$ & 468 & 2.10 & 8.90 & 3.03 & 0.63 \\
$74 \mathrm{bpm}$ & 516 & 1.60 & 6.90 & 2.94 & 0.52 \\
\hline \multicolumn{5}{c}{} & ※呼吸周期の単位は秒, ptはパーソナルテンポ
\end{tabular}

(2) 打吒時の拍のグループ化

打吒中の呼吸周期をそれに対応する打叨周期で割り，1呼 吸に何打たたいているかの比（R）を算出した。比 Rが \pm 0.1 未満の場合に, グループ化されていると定義した。算出した 比率のうちの一部に, 整数あるいは 0.5 の倍数になる值がみ とめられ，それを計数した(Table 2)。

Table 2 各テンポのグループ化数

\begin{tabular}{|c|c|c|c|c|c|c|c|c|c|}
\hline 比率 & 1 & 1.5 & 2 & 2.5 & 3 & 3.5 & 4 & 計 & 率 \\
\hline $20 \mathrm{bpm}$ & 10 & & & & & & & 10 & $76.92 \%$ \\
\hline $26 \mathrm{bpm}$ & 2 & 1 & 1 & & & & & 4 & $33.33 \%$ \\
\hline $33 \mathrm{bpm}$ & & 1 & 2 & & & & & 3 & $23.08 \%$ \\
\hline $43 \mathrm{bpm}$ & & & 2 & 3 & & & & 5 & $41.67 \%$ \\
\hline $57 \mathrm{bpm}$ & & & & 3 & 3 & 1 & & 7 & $58.33 \%$ \\
\hline $74 \mathrm{bpm}$ & & & & & 1 & 3 & 3 & 7 & $53.85 \%$ \\
\hline
\end{tabular}

※総数は $20,33,74 \mathrm{bpm}$ については 13 ，他は 12

グループ化率はテンポにより異なっていた。20bpmにおい てグループ化率が高いのは，20bpm は成人の平均的呼吸数で あり人間の生理的テンポとの関連が考えられる。

(3)グループ化と主観

「うまく合わせることができたか」の項目得点(5 件法)につ いて, 1 要因の分散分析を行った結果, 有意差が認められた $(F(5,69)=15.91 p<.001)$ 。下位検定の結果 $20 \mathrm{bpm}$ (平均 2.25$)$ に ついては，ほかの 5 テンポ(平均 $2.50 \sim 3.92$ )よりも有意にう まく合わせられなかったという結果だった。20bpmのグルー プ化率は高かったが，主観的には合わせにくいテンポだと言 える。

人は周期性の運動テンポに応じて呼吸周期を変え, 拍をグ ループ化して合わせることでタイミングを制御している可能 性が示唆された。仮説は支持されたと言える。また，テンポ によるグループ化の程度と, 呼吸の合わせやすさやタイミン グの取りやすさとの関連性については今後の検討事項とする。 